\title{
Correction
}

\section{Correction: Abughanam, G., et al. Mesenchymal Stem Cells Extract (MSCsE)-Based Therapy Alleviates Xerostomia and Keratoconjunctivitis Sicca in Sjogren's Syndrome-Like Disease. Int. J. Mol. Sci. 2019, 20, 4750}

\author{
Ghada Abughanam (D, Osama A. Elkashty (D, Younan Liu, Mohammed O. Bakkar and Simon D. Tran*(D)
}

check for updates

Citation: Abughanam, G.; Elkashty, O.A.; Liu, Y.; Bakkar, M.O.; Tran, S.D. Correction: Abughanam, G., et al. Mesenchymal Stem Cells Extract (MSCsE)-Based Therapy Alleviates Xerostomia and Keratoconjunctivitis Sicca in Sjogren's Syndrome-Like Disease. Int. J. Mol. Sci. 2019, 20, 4750. Int. J. Mol. Sci. 2021, 22, 894.

https://doi.org/10.3390/ijms22020894

Received: 3 November 2020 Accepted: 10 November 2020 Published: 18 January 2021

Publisher's Note: MDPI stays neutral with regard to jurisdictional clai$\mathrm{ms}$ in published maps and institutional affiliations.

Copyright: () 2021 by the authors. Licensee MDPI, Basel, Switzerland. This article is an open access article distributed under the terms and conditions of the Creative Commons Attribution (CC BY) license (https:// creativecommons.org/licenses/by/ $4.0 /)$.
McGill Craniofacial Tissue Engineering and Stem Cells Laboratory, Faculty of Dentistry, McGill University, Montreal, QC H3A 0C7, Canada; ghada.abuelghanam@mail.mcgill.ca (G.A.); osama.elkashty@mail.mcgill.ca (O.A.E.); Younan.liu@mcgill.ca (Y.L.); mob11@case.edu (M.O.B.)

* Correspondence: simon.tran@mcgill.ca

The authors wish to make the following corrections to this paper [1]:

Figure 2B was mistakenly replaced by Figure 2D, the corrected Figure 2 is shown below:
(A)

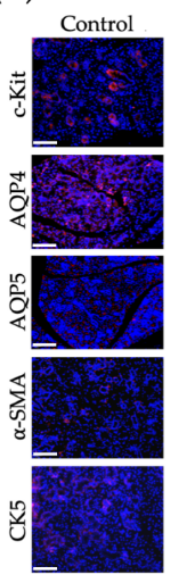

(C)
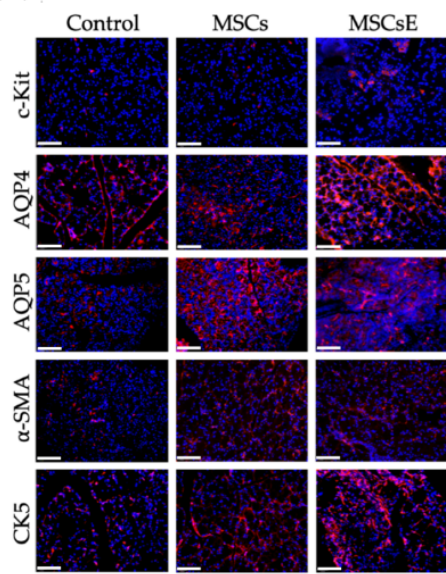

(B)
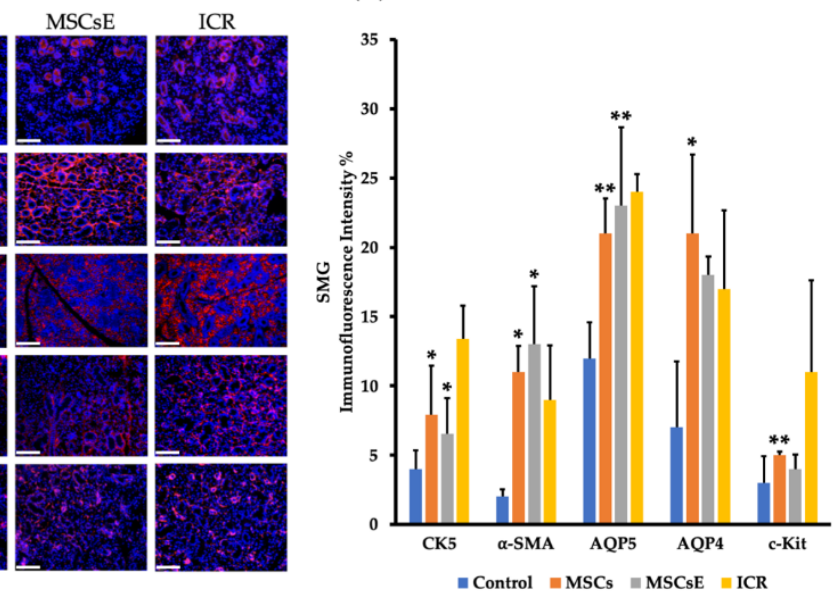

(D)

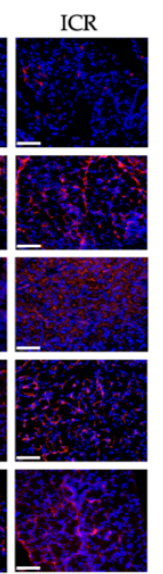

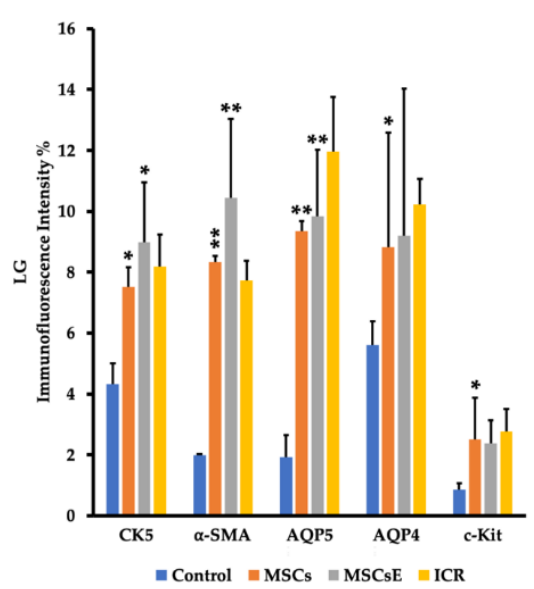

We apologize for any inconvenience brought to the readers. 


\section{Reference}

1. Abughanam, G.; Elkashty, O.A.; Liu, Y.; Bakkar, M.O.; Tran, S.D. Mesenchymal Stem Cells Extract (MSCsE)-Based Therapy Alleviates Xerostomia and Keratoconjunctivitis Sicca in Sjogren's Syndrome-Like Disease. Int. J. Mol. Sci. 2019, $20,4750$. [CrossRef] [PubMed] 